\title{
Histopathological Changes in Incisive Teeth of the Newborn Pups of Cadmium-Applied Female Rats during Pregnancy
}

\author{
Cambios Histopatológicos en Dientes Incisivos de Crías Neonatos \\ de Ratas Hembras bajo Suministro de Cadmio durante la Preñez
}

\author{
"Ssenay Deveci \& **Engin Deveci
}

\begin{abstract}
DEVECI, $S_{s}$. \& DEVECI, E. Histopathological changes in incisive teeth of the newborn pups of cadmium-applied female rats during pregnancy. Int. J. Morphol., 28(4):1131-1134, 2010.

SUMMARY: Cadmium Chloride is a well known teratogen compared to other metals. Cadmium affects placental function, may cross the placental barrier and modify fetal development. In this study, 12 female wistar albino rats weighted between 180-200gr were used. They were divided into two groups as experimental and control groups each comprising 6 female animals. $2 \mathrm{mg} / \mathrm{kg} / \mathrm{day}$ cadmium chloride dissolved in $1 \mathrm{ml}$ isotonic solution were intravenously injected from tail vein of experimental rats during 17-21 days of pregnancy. At first day of birth, the total body weights of control and experimental newborn pups were taken. This study aims to evaluate morphologically the effects of cadmium chloride on the incisive teeth development of pups born to the cadmium-applied female rats during pregnancy.
\end{abstract}

KEY WORDS: Cadmium; Tooth; Pregnancy.

\section{INTRODUCTION}

Human exposure to cadmium due to environmental factors is known to affect several tissues in the body. The major sources of exposure to cadmium are contaminated food and water, tobacco, and industrial fumes and dusts (Goyer $\&$ Cherian, 1995). It has been shown that long-term exposure of pregnant female rats to $\mathrm{Cd}$ results in foetal growth retardation and teratogenic effects. Cadmium is also accumulated in calcified tissues, like bone and teeth (Fosse \& Wesenberg, 1981). During pregnancy, cadmium is retained in the placenta, which acts as an important, but not complete, barrier to protect the fetus from cadmium exposure. It has been shown in rodents as well as in humans (Loiacono et al., 1992).

Some investigators, environmental cadmium exposure was associated with caries scores in deciduous teeth but not in the permanent teeth. Furthermore, some epidemiologic investigations of environmental lead exposure have also observed significant associations with caries only in deciduous teeth (Gemmel et al., 2002; Youravong et al., 2006), suggesting that deciduous teeth may be more sus- ceptible than permanent teeth to environmental toxins. The aim of this study is to investigate the histological changes in incisive teeth of fetus whose mothers treated with cadmium during pregnancy and also to determine the developmental defects in fetal teeth.

\section{MATERIAL AND METHOD}

In this study, 12 female wistar albino rats weighted between 180-200gr were used. They were coupled with male rats. Vaginal smears were examined under microscopy to determine the pregnancy. Pregnant female rats were placed in different cages at 1 st day of pregnancy. They were divided into two groups as experimental and control groups each comprising 6 female animals. $2 \mathrm{mg} / \mathrm{kg} / \mathrm{day}$ cadmium chloride dissolved in $1 \mathrm{ml}$ isotonic solution were intravenously injected from tail vein of experimental rats during 17-21 days of pregnancy. $1 \mathrm{ml}$ isotonic solution without heavy metal were similary injected into control rats. Throughout the

\footnotetext{
* Department of Nurse, Dicle University Atatürk Health Faculty, Diyarbakır, Turkey.

** Department of Histology and Embryology,Dicle University Medical Faculty, Diyarbakır, Turkey.
} 
experiment, a 12-h light and dark cycle was maintained, with lights on from 06:00 to 18:00 h. The temperature was maintained at $23^{\circ} \mathrm{C}$, and the relative humidity ranged between 55 and $60 \%$. Standard rat chow and tap water were available ad libitum to the experimental animals.

Histological changes were observed degeneration in enamel, dentin and cement layers of the upper incisive teeth of newborn pups of the cadmium applied rats (Fig.1).

At first day of birth, newborn pups were divided into two groups. The total body weights of control and experimental newborn pups were taken (Table I). The maxillary regions were dissected under ketamine hidrochloride anesthesia and placed in 10\% formaldehide solution. They were placed in parafine inclusion melted at $58^{\circ} \mathrm{C}$ after treatment with xylol, the $4-6 \mu \mathrm{m}$ sections were taken by rotary microtome and the sections were stained with Hematoxylene-Eosin (H-E) dyes and then observed under Olympus BH2 light microscopy to determine histological changes.

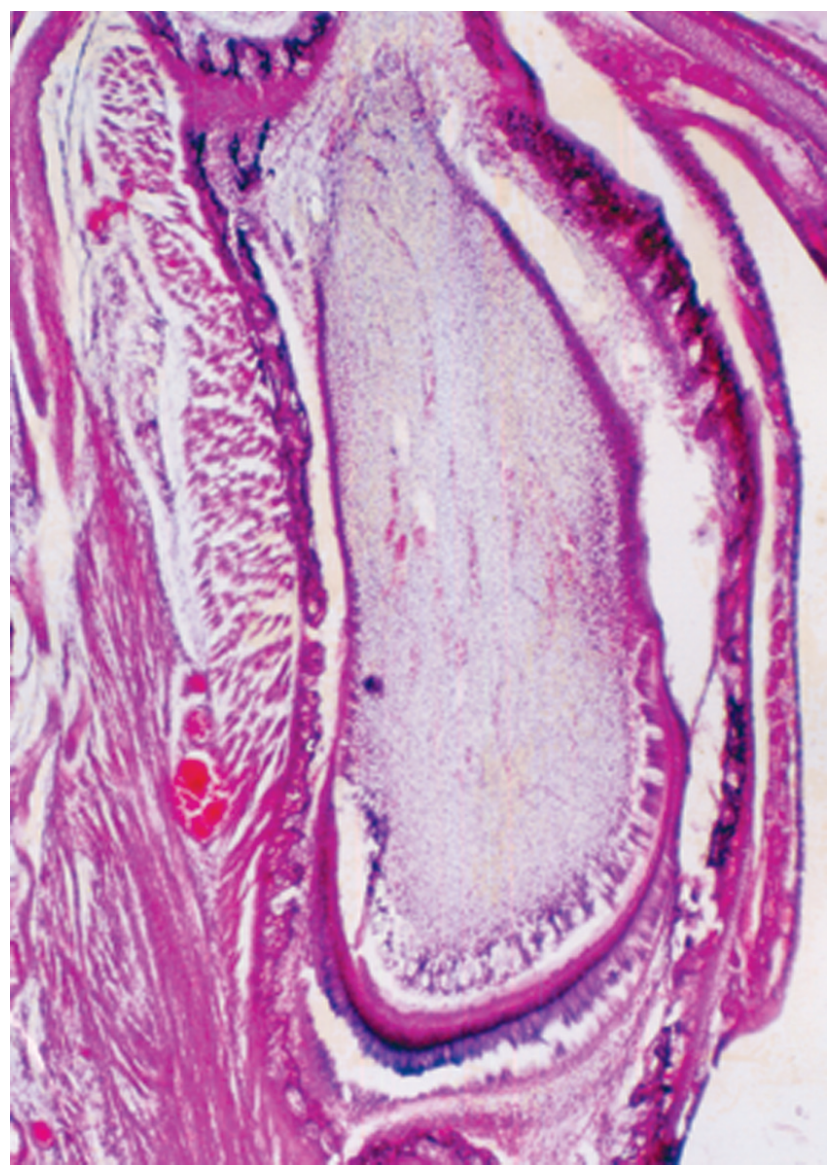

Fig. 1. Degeneration in enamel, dentin and cement layers of the upper incisive teeth of newborn pups (H-E X41).
Table I. Total body weights of experiment and control groups.

\begin{tabular}{lccc}
\hline Groups & ${ }^{-} \mathrm{X}$ & $\mathrm{SD}$ \\
\hline Experiment $\quad(\mathrm{n}=30)$ & 8.23 & 3.09 \\
Control $\quad(\mathrm{n}=20)$ & 10.34 & 3.37 \\
\hline
\end{tabular}

\section{RESULTS}

Results show that the average body weights and standard deviations of control and the experimental group pups of the cadmium applied female rats during pregnancy. It is clearly seen that the body weights of experimental group pups are lower than those of control group $(\mathrm{P}<0.001)$.

A clear slendering of enamel organ, indistinct ameloblast cells, hyperplasia and mitotic increase in odontoblast cells were observed. In addition, free-floating erytrocytes in pulpa tissue and mononuclear lymphocyte

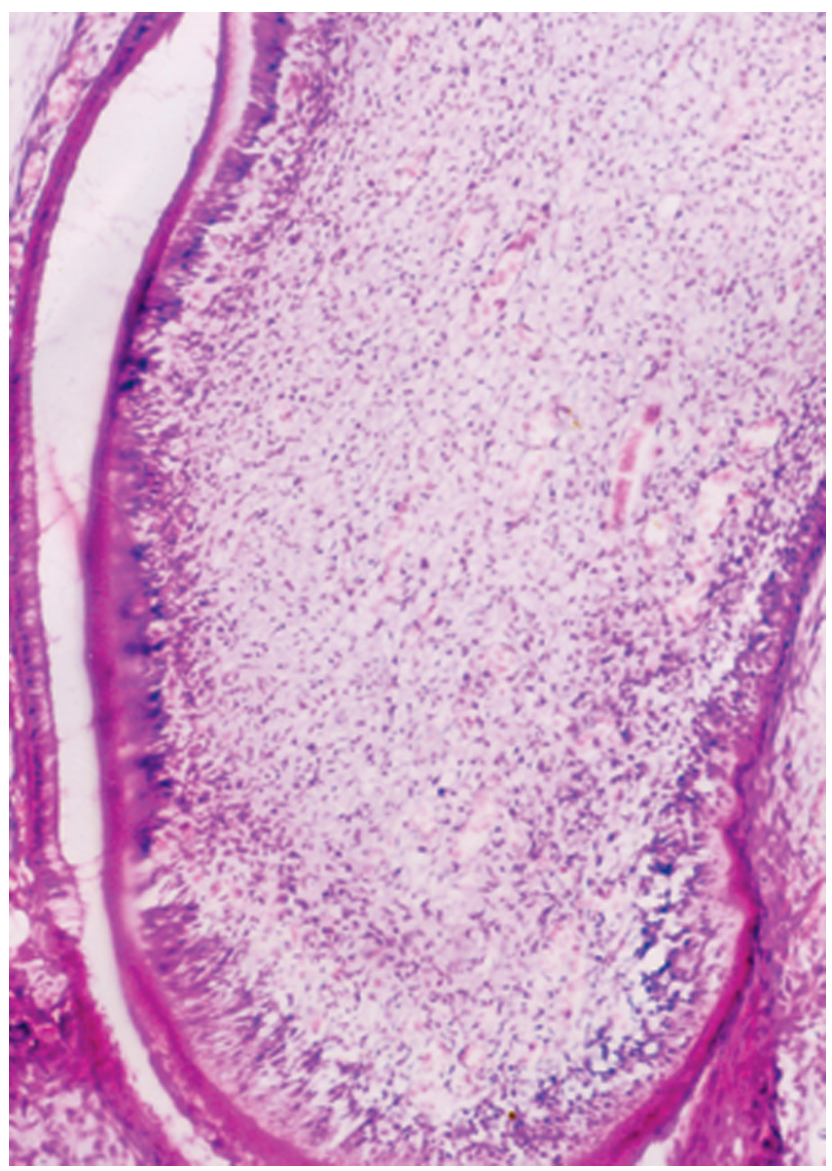

Fig. 2. Hyperplasia in ameloblast cells, mitotic increase in odontoblast cells (H-E X41). 


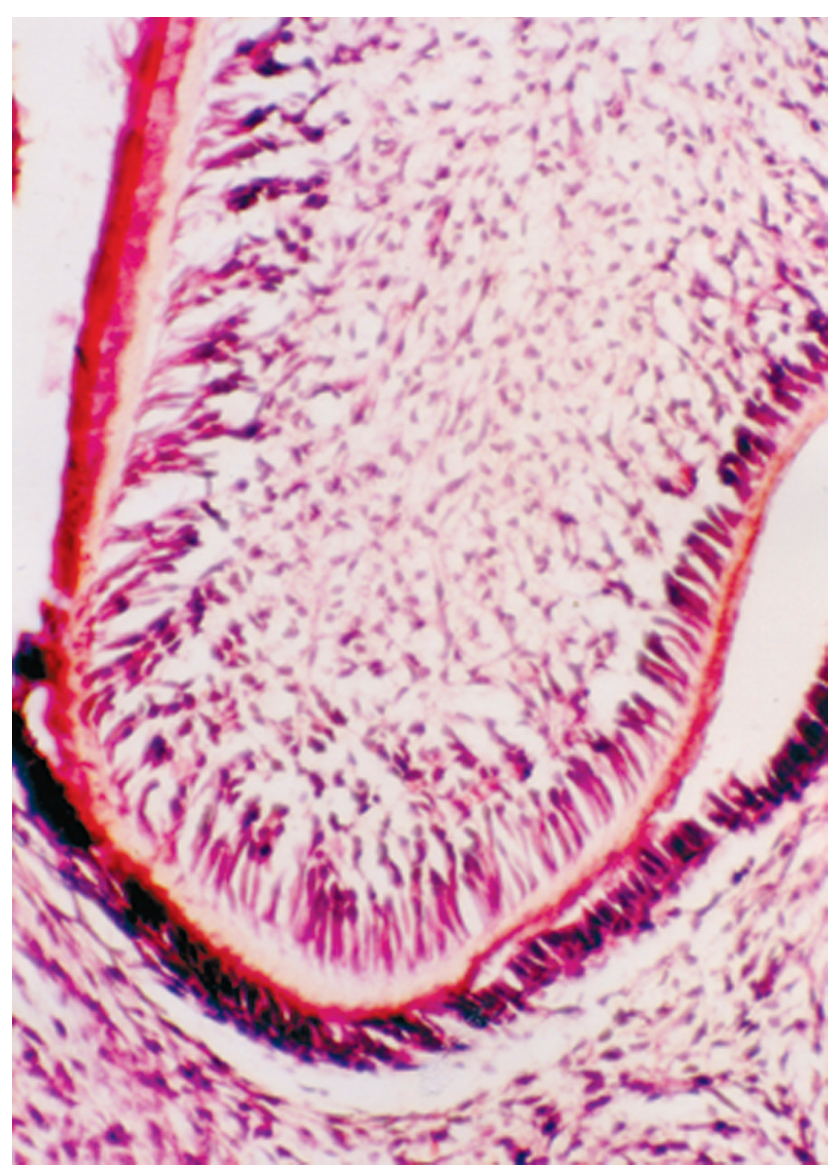

Fig. 3. A dense infiltration of lymphocyte between pulpa and dentin, dilatation in blood vessels of pulpa tissue (H-EX82).

infiltration were seen in most places (Fig. 2). A dense infiltration of lymphocyte between pulpa and dentin, dilatation in blood vessels of pulpa tissue were observed (Fig. 3). The mitotic activity of all area is dense and there is no pathological symptom in the sections of control group.

\section{DISCUSSION}

Cadmium is perhaps one of the most toxic industrial and environmental metals and it continues to be a health hazard. In this study, a significant lower body weight of pups of animals intoxicated with cadmium was observed. Reduced pup weight was also observed in rats by Crowe \& Morgan (1997), and in newborn lambs by Floris et al. (2000). The decrease in birth weight could be due to a deficit in iron and/or zinc in cadmium-contaminated dams. It has been shown that cadmium induces maternal zinc retention, which is responsible for fetal zinc deficiency and impaired fetal growth (Sorell et al., 1990).
Some of researcher showed the effects of different metals on teeth during embryonic stage and also claimed that cadmium may cause a blockage during teeth eruption and root eruption (Hamada, 1989). Katsuta et al. (1996) studied the effects of cadmium in molar and incisive teeth and observed a reduction at iron pigment in ameloblast cells and damage at enamel organ of incisive teeth. Following iron reduction, cadmium accumulation increased in teeth. The necrosis of dental pulpa was developed from coronal region to apical in both molar and incisive teeth. In our study we observed slendering in enamel organ, mononuclear cell infiltration in pulpa tissue rarely bleeding sites (Fig. 2). Furthermore, a free-floating erythrocytes and lymphocyte infiltration in vessels of dentin pulpa and periodontal membrane were observed due to cadmium effects (Fig. 3).

In a rat study, where the effect of lead on enamel formation was investigated, no macroscopical changes could be seen other than indications of altered mineralization. A relative increase in the amount of protein was detected, possibly resulting in a decrease in the micro hardness of the rat enamel (Gerlach et al., 2002). The intraperitoneal injection of cadmium induces the synthesis of metallothionein in the papillary epithelial layer of the secretory zone, in a single layer of epithelial cells of the presecretory zone and within ameloblasts of the postsecretory zone of the enamel organ in rat incisor teeth (Tamura et al., 1999). Prospective epidemiologic studies are needed to confirm these findings and to understand the mechanisms behind the observed association between cadmium and dental histopathology.

DEVECI, $\mathbf{S}_{\boldsymbol{s}}$ \& \& DEVECI, E. Cambios histológicos en dientes incisivos de cachorros neonatos de ratas hembras bajo suministro de cadmio durante el embarazo. Int. J. Morphol., 28(4):1131-1134, 2010.

RESUMEN: Cloruro de cadmio es un teratógeno conocido en comparación con otros metales. El cadmio afecta la función placentaria, pudiendo atravesar la barrera placentaria y modificar el desarrollo del feto. Fueron utilizadas 12 ratas hembras Wistar albinas, entre 180-200g de peso. Se dividieron en dos grupos de seis hembras cada uno, grupo experimental y control. Se inyectó, a través de una vena de la cola de las ratas del grupo experimental por vía endovenosa $2 \mathrm{mg} / \mathrm{kg}$ /día de cloruro de cadmio disuelto en 1 ml de solución isotónica, durante 17-21 días de gestación. Al primer día de nacimiento, se pesaron las crías de los grupos control y experimental. Este estudio tiene como objetivo evaluar morfológicamente los efectos del cadmio sobre el desarrollo de los dientes incisivos de crías recién nacidas de ratas hembras a quienes se les inyectó cadmio durante la preñez.

PALABRAS CLAVE: Cadmio; Dientes; Preñez. 
DEVECI, S. \& DEVECI, E. Histopathological changes in incisive teeth of the newborn pups of cadmium-applied female rats during pregnancy. Int. J. Morphol., 28(4):1131-1134, 2010.

\section{REFERENCES}

Crowe, A. \& Morgan, E. H. Effect of dietary cadmium on 1ron metabolism in growing rats. Toxicol. Appl. Pharmacol., 145:136-46, 1997.

Floris, B.; Bomboi, G.; Sechi, P.; Pirino, S. \& Marongiu, M. L. Cadmium chronic administration to lactating ewes: redroductive performance, cadmium tissue accumulation and placental transfer. Ann. Chim., 90:703-8, 2000.

Fosse, G. \& Wesenberg, G. B. R. Lead, cadmium, zinc and copper in deciduous teeth of Norwegian children in the pre-industrial age. Int. J. Environ. Stud., 16:163-70, 1981.

Gemmel, A.; Tavares, M.; Alperin, S.; Soncini, J.; Daniel, D.; Dunn, J.; Crawford, S.; Braveman, N.; Clarkson, T. W.; Mckinlay, S. \& Bellinger, D. C. Blood lead level and dental caries in school-age children. Environ. Health Perspect., 110:A625-30, 2002.

Gerlach, R. F.; Cury, J. A.; Krug, F. J. \& Line, S. R. Effect of lead on dental enamel formation. Toxicology, 175:2734, 2002.

Goyer, R. A. \& Cherian, M. G. (Eds). Toxicology of Metals: Biochemical Aspects, Handbook of Experimental Pharmacology. New York, Springer-Verlag, 1995. pp. 189-213. V. 115.

Hamada, S. Study of trace elements in bovine permanent teeth germ. Kanagawa Shigahu, 24(1):24-37, 1989.

Katsuta, O.; Hiratsuka, H.; Matsumoto, J.; Tsuchitani, M. \& Umemura. T. Cadmium-induced dental lesions in ovariectomized rats.Toxicol. Pathol., 24(4):451-7, 1996.

Loiacono, N. J.; Graziano, J. H.; Kline, J. K.; Popovac, D.; Ahmedi, X.; Gashi, E.; Mehmeti, A. \& Rajovic, B. Placental cadmium and birthweight in women living near a lead smelter. Arch. Environ. Health, 47:250-5, 1992.

Sorell, T. L, Graziano, J. H. Effect of oral cadmium exposure during pregnancy on maternal and fetal zinc metabolism in the rat. Toxicol. Appl. Pharmacol., 102:537-45, 1990.

Tamura, Y.; Wysocki, G. P. \& Cherian, M. G. Immunohistochemical localization of metallothionein in the developing teeth of cadmium-injected rats. Arch. Oral Biol., 44(1):49-53, 1999.
Youravong, N.; Chongsuvivatwong, V.; Geater, A. F.; Dahlén, G. \& Teanpaisan, R. Lead associated caries development in children living in a lead contaminated area, Thailand. Sci. Total Environ., 361:88-96, 2006.

Correspondence to:

Engin Deveci

Dicle University, Medical Faculty,

Histology and Embryology Dept.

21280 Diyarbakır

TURKEY

Tel:9004122488001/4443

Fax:9004122488435

Email:engindeveci64@gmail.com

Received: 23-03-2010

Accepted: 19-08-2010 